\title{
8. Who are the members of truth commissions?
}

\section{Dietlinde Wouters}

\section{INTRODUCTION}

Governments of countries in political transition after a period of severe violence, such as a repressive dictatorship or a civil war, have to make important decisions about how to deal with the violent events of the past. The form of justice associated with these periods of political change is called transitional justice (Teitel, 2003). Since the 1980s, truth commissions have been a popular mechanism in these contexts. A truth commission can be defined as:

[...] an ad hoc, autonomous, and victim-centered commission of inquiry set up in and authorized by a state for the primary purpose of (1) investigating and reporting on the principal causes and consequences of broad and relatively recent patterns of severe violence or repression that occurred in the state during determinate periods of abusive rule or conflict, and (2) making recommendations for their redress and future prevention. (Freeman, 2006: 18)

Truth commissions play an important role in a country's transitional justice process (e.g. Bakiner, 2016; Brahm, 2007). Therefore, the selection of members of the commission - hereafter commissioners - is a crucial decision. Commissioners of truth commissions seem to have notably divergent professions and backgrounds. Some of the professions are rather surprising, e.g. physician/author, cardiologist, engineer and philosopher in the case of the truth commission of Argentina. This observation raises the question of why particular commissioners are selected. ${ }^{1}$

This question is sometimes (briefly) answered as part of a broader discussion of a particular truth commission (e.g. Crenzel, 2012 on Argentina; Kritz, 1995 on Chile). The comparative literature on the topic, such as Freeman (2006) and Hayner (2011) who both discuss some contrasting cases with respect to different selection procedures, has an overall descriptive character. Other analyses have a more normative character and formulate specific recommendations for 
the selection of the commissioners (e.g. Amnesty International, 2007; Office of the United Nations High Commissioner for Human Rights, 2006).

In this chapter I wish to go further than the existing scholarship and in doing so I am interested in the broader question of whether we can detect an epistemic profile of commissioners of truth commissions in general. My approach contains both descriptive and normative elements, however, clearly different from the examples given above. Through a comparative-conceptual analysis comparing different truth commissions as well as different forms of commissions mainly focusing on the concepts of objectivity and representivity, I arrive at an epistemic profile of commissioners of truth commissions. An epistemic profile, in the way that I use it here, describes aspects related to the agents' knowledge, their knowledge production and the way they pass knowledge on to others. The profile in this chapter is descriptive, but also has normative implications. This epistemic profile does not prescribe binding selection criteria for the commissioners, but rather it is normative in the sense that it indicates the importance of certain concepts and ideas that policymakers should take into account when composing a truth commission. It can offer us a better understanding of the often only implicit ideas and values at play related to the selection of truth commissioners, independent of the particular political context.

For this chapter I draw on the work of Ashforth in his article 'Reckoning Schemes of Legitimation: On Commissions of Inquiry as Power/Knowledge Forms' (1990). The article does not specifically discuss truth commissions, but commissions of inquiry in general. Based on his findings, Ashforth states that there are two basic types of criteria generally considered by governments when deciding membership of a commission of inquiry: representativeness of particular sectoral interests and expertise (Ashforth, 1990). Ashforth furthermore discusses three sources from which a commission's authority is derived. First, the authority of the high-level political authorities that select a commission gives this new commission credibility and authority. Second, commissions have authority because of the status and expertise of their members and, third, the supposedly rational, impartial, objective and independent procedures give authority to the commission's findings (ibid.). Both topics, the required characteristics of the commissioners and the commission's authority, are addressed in this chapter. However, in the epistemic profile I develop, I will propose other characteristics for the commissioners of truth commissions, and I will suggest another source for the commission's authority, that of the composition of the overall commission.

The cases of Argentina, Chile, El Salvador and South Africa will serve as the basis of my analysis. I will start this chapter with a brief presentation of these truth commissions, especially focusing on the aspects related to the selection of the commissioners. Drawing on Ashforth's (1990) work as out- 
lined above, I then explore how the different compositions of the selected truth commissions can be interpreted according to different ideals of objectivity. The composition of these truth commission can be seen as an additional source of authority for both the commissions and its results.

In the second part of this chapter, I examine what kind of representative role commissioners are expected and supposed to play. In order to do so, I first consider two comparable but contrasting bodies: the expert commissions of the European Commission (hereafter EC) and the jury of an assize court. These two can be placed at two extremes of a continuum: the members of an expert commission can be called subject matter experts, whereas jurors are both laypeople (non-experts) and peers. A comparison between these commissions and truth commissions indicates that the commissioners of a truth commission occupy a place somewhere in between these two extremes. A member of a truth commission should ideally represent all of the victims, the parties involved and society at large, a requirement that neither the subject matter expert nor the layman-peer seem able to meet. I then proceed with an overall comparison of the backgrounds and professions of commissioners which leads, in combination with the analysis in the first part of the chapter, to a general, epistemic profile of the commissioners of the selected cases. In contrast to Ashforth, I state that the commissioners do not necessarily need to be subject matter experts. Their epistemic profile exists in having a good status, possessing the necessary intellectual and research capacities and being able to represent certain groups, in direct or indirect ways. It is important to highlight that the epistemic profile alone is not enough. The commissioners can never fulfil their tasks in a completely objective way, in the sense of being value-free. That is why not only the profile of the commissioner but also the composition of the commission is crucial.

\section{BRIEF DISCUSSION OF THE SELECTED CASES}

In this section, I will outline the characteristics of the truth commissions of Argentina (1983-4), Chile (1990-1), El Salvador (1992-3) and South Africa (1995-2002), with a focus on the aspects relevant for the selection of the commissioners. These truth commissions were selected because of the relevant differences in the selection procedures of the commissioners and the final composition of the commissions. As can be seen below there is some variety in how the commissions were conceived, their mandates and purpose, as well as any specifications regarding the selection of commissioners. However, all four cases share some important similarities. They represent some of the earliest, most defining examples of truth commissions that contributed considerably to shaping not only how later truth commissions were conceptualized and shaped, but they also defined the field of transitional justice beyond criminal justice 
(Bell, 2009) both as an academic enquiry and a practice for decades to come. While all four commissions differ in how their commissioners were selected, they all sought to learn from and support each other as they shaped their transitions. This exchange most notably took place at a series of conferences in the late 1980s and early 1990s at which key figures from all four contexts were present (Mouralis, 2013). They can thus be presumed to have influenced each other. Members of the South African Commission then went on to shape transitional justice processes elsewhere, most notably through the founding of the International Center for Transitional Justice by the Deputy Chairperson of the South African TRC Alex Boraine and the truth commission scholar Priscilla Hayner (Vinjamuri and Snyder, 2004). Their importance in shaping both truth commissions and transitional justice more broadly makes them crucial cases for the analysis of the selection processes of the commissioners of truth commissions.

The Comisión Nacional sobre la Desaparición de Personas (National Commission on the Disappearance of Persons, hereafter CONADEP) was established in 1984 by president Raúl Alfonsin by means of Presidential Decree no. $187 / 83$. The objective of the commission was to investigate what had happened during the recent Argentine military dictatorship (1976-83). The presidential decree appointed the first ten members of the commission (CONADEP, 1984: part IV). It was originally intended that both Chambers of Congress would each select three additional members, but only the Chamber of Deputies did so. As a result, the commission consisted of 13 members in total (CONADEP, 1984: cap. 4.I; Hayner, 1994; Presidential Decree 187/83, Art. 7).

The Chilean Comisión Nacional de Verdad y Reconciliación (Truth and Reconciliation Commission) was created in 1990 by president Patricio Aylwin to investigate the human rights violations which occurred during the Chilean dictatorship of Pinochet (1973-90). ${ }^{2}$ The president selected the eight commissioners of the commission based on their human rights background, their prestige and authority. He personally invited people with different political affiliations to avoid (the impression of) political bias (Kritz, 1995; Supreme Decree 355: Art. 8).

The Salvadoran commission (Comisión de la Verdad para El Salvador) was established as part of the United Nations (UN) guided peace agreements between the Salvadoran government and the Farabundo Martí National Liberation Front (FMLN) guerrilla movement, in order to put an end to the civil war (1979-90s). Under the Mexico Agreements of April 1991, both parties accepted the UN proposal to create a truth commission (Doggett and Kircher, 2005). Following long discussions, the parties agreed to establish a commission composed of foreigners, while the planned ad hoc commission ${ }^{3}$ would be composed of nationals (Americas Watch, 1993; Jowdy, 1997). The 
commission's mandate prescribed that the three members of the commission should be appointed by the UN Secretary-General, with input from the parties involved.

The South African Truth and Reconciliation Commission (TRC) was established in 1995 by the Promotion of National Unity and Reconciliation Act, in order to investigate the human rights violations committed during the Apartheid regime (1948-91). The following official instructions were given under the Act regarding the appointment of the commissioners:

The commission shall consist of not fewer than 11 and not more than 17 commissioners, as may be determined by the president in consultation with the cabinet.

(a) The president shall appoint the commissioners in consultation with the cabinet.

(b) The commissioners shall be fit and proper persons who are impartial and who do not have a high political profile: provided that not more than two persons who are not South African citizens may be appointed as commissioners. (Promotion of National Unity and Reconciliation Act, 1995: Art. 7)

The Act only prescribed that the members of the commission should be appointed by the president in consultation with the cabinet, but the final selection process was more inclusive. During the first phase, the public was invited to send in nominations, which resulted in a first list of 299 candidates. Then, a special committee consisting of members of parliament and people from the non-governmental organization (NGO) community made a first selection and invited them for public hearings. After the hearings, a final list of 25 candidates was compiled and passed on to the president. During the final phase, President Mandela selected 15 members from this list in consultation with his cabinet and with the heads of the political parties. The president also added two extra members to make the commission more representative of South African society (Shea, 2000; Verdoolaege, 2005). The final commission thus counted 17 members $^{4}$ and contained commissioners of each of the apartheid's race categories, of the full range of political backgrounds (from the left to the conservative, white right wing) and of different religious beliefs (Christian, Muslim, Hindu and agnostic) (Tutu, 1999; Verdoolaege, 2005).

\section{THE COMPOSITION OF TRUTH COMMISSIONS}

In her article 'The Practices of Objectivity in Regulatory Science' (2011), Sheila Jasanoff investigates how policy-relevant knowledge of investigative and advisory commissions gains authority. Comparable to those commissions, truth commissions also generate policy-relevant knowledge. To have political impact, authority is important for all three kinds of commissions. Jasanoff argues that the authority of investigative and advisory commissions rests on their objectivity. Demonstrations of objectivity can protect the com- 
mission from suspicion of arbitrariness or self-interest. She further explains that different countries may have different styles of epistemic legitimation to constitute the objectivity of the commissions and of the knowledge they produce (Jasanoff, 2011). She compares three countries (the United States (US), Great Britain and Germany) in this respect and differentiates between two main approaches, namely the view from nowhere ${ }^{5}$ (US) and the view from everywhere (Great Britain and Germany). I will argue that the authority of truth commissions also depends on often implicit objectivity claims and we can identify different ways of constituting objectivity. Below, I briefly present the American, British and German approaches discussed in Jasanoff's article and then show how this analysis applies to the selected truth commissions.

The view from nowhere, used to describe the American approach, is an approach to claims-making "by ostensibly detaching knowledge from potentially biased standpoints and from the distortions that any perspective or viewpoint necessarily entails' (ibid.: 309). In the American context of science-based regulation, policymakers adhere to the idea that facts speak for themselves and that scientific advice can be impartial. The personal aspects of knowledge producers, such as their personalities, personal opinions or viewpoints, should not have any effect on their knowledge production and even become irrelevant if they do their job correctly. US policymakers minimize the effects that agency, subjectivity and human decision-making might have. Instead they promote strategies of depersonalization and present their decisions as based solely on scientific evidence (ibid.: 312-313).

The view from everywhere approach, on the other hand, assumes that decisions cannot be made free from all values, but rather should be taken from a position that is balanced or neutral with respect to a spectrum of views and values. In the UK, elite figures are asked to form part of investigative and advisory commissions. This decision is not only taken because of their social status, but also because they are supposed to 'articulate a plain, common-sense vision: knowledge whose truthfulness anyone in society, from the highest to the lowest, can in theory review and attest to' (ibid.: 313) The results of such a commission are said to be objective, because they emerge from a truly communal view, a view from everywhere (ibid.). The same expression, a view from everywhere, circumscribes the kind of objectivity pursued in the German context of policy-relevant knowledge production. However, its implementation is different. In Germany, expert bodies produce common knowledge through a process of group reasoning in which ideally all the involved parties are represented. The validity of the expert consensus depends on the inclusion of all standpoints. If not all standpoints are represented, this has a negative impact on the objectivity of the results (ibid.: 314).

Truth commissions are also intended to produce objective knowledge. The different ways of attempting to achieve this aim can be mapped onto the 
objectivity ideals that seem to have been pursued during the selection of commissioners for the truth commissions described above. The American form of objectivity, which uses strategies of depersonalization and focuses mainly on scientific evidence, is similar to how the Salvadoran commission was organized, as revealed by two of its main characteristics. First, the commission consisted only of foreign members. This was a way of creating distance between the commissioners and the subject of investigation and between the commissioners and Salvadoran society. According to the FMLN guerilla movement, a commission of Salvadorans would conduct the investigation in a less rigorous way because of political pressure and fear of violence (Americas Watch, 1993; Jowdy, 1997). Second, the Salvadoran commission also put a remarkably strong emphasis on rigorous and reliable methodology. They decided to submit all the information gathered to a strict reliability test. Information had to be verified, proven and re-examined before it was accepted as a reliable fact $^{6}$ (United Nations, 1993). Consequently, attention was shifted away from the personalities and the backgrounds of the commissioners, helping to constitute a view from nowhere from which objective knowledge can be produced.

The commissions of Argentina, Chile and South Africa were established according to the idea of objectivity as a view from everywhere. In Argentina, the president invited people 'who enjoyed national and international prestige, chosen for their consistent stance in defense of human rights and their representation of different walks of life' (CONADEP, 1984: part IV). The CONADEP was a commission of notables. The focus on prestige and the fact that representivity was not a necessary condition fit in with the British idea of objectivity in which elite figures are asked to form part of a commission. The Chilean and South African commissions, on the other hand, tended to follow the German version of the view from everywhere with representation of the full social spectrum of views being central to the composition of these commissions. However, it is probably more accurate to speak of a mixed view in these cases, in which different objectivity ideals coexist. There was not only a focus on representivity but also on members having, as in the British approach to objectivity, a certain prestige and authority. The Chilean president selected and personally invited the eight commissioners of the Chilean truth commission, based on their human rights background, and their prestige and authority (Supreme Decree 355: Art. 8; Kritz, 1995). At the same time, he tried to include commissioners with different political affiliations to avoid political bias (Kritz, 1995). The selection procedure of the members of the South African TRC was a democratic and open process resulting in a commission of well-known members. The final decision was made by President Mandela who explicitly emphasized the importance of representivity. He added two extra members who had not been on the list of the selection committee, in order to make the commission more representative of South African society 
(Verdoolaege, 2005). In contrast to the Chilean commission, representation and representivity were not only interpreted in respect to the members' political affiliations. The TRC also contained members of each of the apartheid race categories and members with different religious beliefs (Christian, Muslim, Hindu, agnosticism).

\section{REPRESENTIVITY IN TRUTH COMMISSIONS}

\section{A Spectrum of Representation}

For the view from everywhere, representation is a crucial concept. Political representation generally exhibits the five following components:

Some party that is representing (the representative, an organization, movement, state agency, etc.);

Some party that is being represented (the constituents, the clients, etc.);

Something that is being represented (opinions, perspectives, interests, discourses, etc.);

A setting within which the activity of representation is taking place (the political context); and

Something that is being left out (the opinions, interests, and perspectives not voiced). (Dovi, 2017: section 1)

I will show that these components provide a useful framework for discussing representation in the context of truth commissions' work as well.

For the German form of the view from everywhere, representivity, in other words how representative a commission is for the group it represents, is very important. To know whether a (political) representation can be called representative, the question should be answered as to whether the party that is representing (component 1) represents the opinions, perspectives, interests, discourses, etc. (component 3 ) of the party that is being represented (component 2) in an adequate way, preferably in as complete a way as possible. When the opinion, interests or perspectives of a relevant group of people are not represented, the representation cannot be called representative. Representations can be more or less representative. Reflection about the first four components reveal information about the fifth component and, hence, about the extent of representivity of the representation.

Representation plays an important role in truth commissions, but also in other kinds of commissions. The meaning of the concept may vary for different (kinds of) commissions. I will briefly explore two specific kinds of commissions where representation plays a prominent role: the expert commissions of the EC and the jury of the Belgian Assize court (Hof van Assisen). ${ }^{7}$ An expert commission is a consultative body which is set up by the EC or its depart- 
ments when external specialist advice is needed for policymaking, often about specific and very technical topics (e.g. climate change policy and artificial intelligence) (EC, 2016). The EC in need of external specialist advice is the setting within which representation in the commission takes place (component 4). Given the objective of the expert commission, it should represent the most recent knowledge available from those with the greatest expertise in the field (components 2 and 3). A commission appropriate to represent these experts and this knowledge should therefore be a commission composed of a selection of these experts (component 1). They can be called subject matter experts. ${ }^{8}$ The official information on the selection of the commissioners on the website of the EC confirms this profile. ${ }^{9}$

A completely different kind of representation and representivity is applied in the context of the jurors of the Belgian assize court (component 4). The principle behind the existence of the jury in the Assize court is the right of the public to participate in the administration of justice (Traest, 2001). It is therefore the opinion of the public that should be represented by the jury (components 2 and 3). In other words, the jury is supposed to offer a view from everywhere. The public is represented by people who are both laypeople and peers of the public (component 1). Peers can be defined as people who are members of the same social set. ${ }^{10}$ Jurors are selected by drawing lots from the most recent list of juror candidates based on the voters' register. ${ }^{11}$ This selection procedure results in a list of random citizens. They are therefore peers of all citizens and hence of the whole of society (ibid.). ${ }^{12}$ The jurors of the Assize court are also called laypeople or lay judges (for example in Traest, 2001). A layperson is a non-expert in relation to some particular profession or branch of knowledge (Oxford English Dictionary). In contrast to professional judges, jurors do not have the same relevant knowledge, education or experience. In fact, people holding legislative, political, judicial or governmental offices are eliminated from the juror candidates' list $^{13}$ (component 5) (Art. 218, Law of December 21, 2009).

The task of the Assize court is to reveal the truth about a crime and to decide on the guilt of the accused. But why would we prefer the judgment of the lay jury over the judgment of professional judges who can be presumed to be the experts in this context? In comparison with other courts, at least three interesting advantages stand out. First of all, the involvement of lay judges is said to provide a better or at least a different kind of judgment. Jury members 'appreciate the moral aspect of the facts in a broader and more human way than professional judges' (Traest, 2001: 46). Second, the jury represents different views, while a professional judge only presents his own view. In addition, the jury decision process is a clearly collective process. The jurors deliberate together before they vote on the question of guilt. Third, the public seems to put more trust in the judgment of the jury and accept their decision more easily 
than that of a professional judge. The verdict of the jury is said to represent public opinion because their members are the public's peers (Duquenne, 2015). Hence, the fact that the case is decided upon by a jury has a positive effect on the general credibility of and trust in its outcome.

So, the expert commissions of the EC and the jury of an assize court can be placed at two extremes of a continuum: the members of an expert commission can be called subject matter experts, whereas jurors are both laypeople (non-experts) and peers. A comparison between these commissions and truth commissions will indicate that the commissioners of a truth commission occupy a place somewhere in between these two extremes.

\section{Representation in Truth Commissions}

The components used to understand how representation works at the expert commission and the jury also help to analyse the practice of truth commissions. The setting of truth commissions (component 4) is the highly political and complex context of a state after a violent period. By organizing the truth commission, the new government seeks to establish a rupture with the violence of the past. The commissions also often initiate or support the national reconciliation process (Hayner, 1994, 1996). Truth commissions are thus often victim-centred, which means that giving a voice to victims is a crucial part of their approach (Freeman, 2006) and their representation is an important aspect. One of the objectives of a truth commission is to compile a report about occurrences during the violent period, ideally one that will be accepted by all parties involved and by society at large. Ideally, therefore, the commission should represent the victims, all the parties involved and the whole society (components 2 and 3). As a consequence, the following questions arise: Who are the people appropriate to represent these groups? What does representation mean here?

\section{Experts or laypeople?}

As explained above, the expert commission (subject matter experts) and the jury of the Assize court (both laypeople and peers) can be seen as two extremes on a continuum. Where exactly on the continuum can we find the members of a truth commission? In comparison with the members of the expert commission, the commissioners of a truth commission clearly have a different profile. To start with, it is more difficult to identify an expert in the context of a truth commission. When the EC looks for members of an expert commission on a specific topic, for example artificial intelligence, it might not be easy to select the best experts in the field, but the kind of expertise they expect from the expert is quite clear. People are chosen to form part of such an expert commission for the specific knowledge they possess on a certain topic. The objective of the commission is to write a report in which the expert knowledge 
of all its members is included. Such a report informs policymakers on the latest developments and the most recent knowledge on the topic. In a truth commission, the expertise and the knowledge of the commissioners alone are not sufficient. Once the commission is formed, the commissioners have to start their investigation and gather relevant information from other sources. Only in a later phase are they able to decide what information to include in the report.

We can say that, although the commissioners of truth commissions might have knowledge about the violent past of the country, they do not necessarily have to be experts whose (factual) knowledge will directly serve the report writing. They might know a lot about the conflict, but it is not this knowledge (alone) that will end up in the report. Interestingly, in some truth commissions, the organizers even try to avoid the inclusion of experts who might already have a strong opinion on what happened. For example, Charles Villa-Vicencio (national research director of the TRC) and Wilhelm Verwoerd (researcher within the TRC) explained that in the South African transitional context the decision was taken to not opt for a "typical, "elitist" commission of experts attempting to produce an authoritative version of the truth' (Villa-Vicencio and Verwoerd, 2000: 289). Instead, they sought 'to implement and manage an inclusive, accessible, and transparent process in order to facilitate a pluralistic public account, generated by diverse individuals "telling their own stories" and a variety of individuals and institutions making submissions' (ibid.: 289). In El Salvador it was decided that the commissioners and their staff would all be foreigners. Although they certainly had expertise in other fields, as non-nationals they clearly had less knowledge of the situation in El Salvador than many Salvadorans at that time. Before they were able to decide which cases to investigate, they had to start with a phase of general fact-finding, in order to achieve a better understanding of the extent and the scope of the violence (Buergenthal, 1995). These examples show that the commissioners of a truth commission are, in some aspects, a kind of laypeople: at the beginning of the process they do not necessarily know more about the conflict than other laypeople (i.e. the normal non-expert population); in some cases, they might even know less. They have no pre-defined, in-depth understandings of the conflict; therefore, they are not subject matter experts. Of course, that they can be seen as laypeople with regards to the conflict context does not mean that they have no expertise or qualities with regards to other relevant topics. This will be discussed in further detail below.

The quote from Villa-Vicencio and Verwoerd is particularly interesting. It suggests some relevant reasons for including laypeople instead of experts with a strong opinion. We cannot be sure that these reasons are valid for all cases, but experts appear to be excluded from truth commissions because their knowledge-forming process is not accessible, transparent or inclusive for a non-expert public. Because the experts have already formed their opinion on 
the topic, this process is already (partially) completed when they start to work on the commission. Both the knowledge-forming process and the knowledge that result from it are therefore not accessible to or transparent for a non-expert public. Such a non-transparent way of communicating seems to suggest that the results are evident. The role of the members' personal background, experiences, beliefs and opinions is left unclear. In other words, such a commission seems to claim a view from nowhere.

\section{Peers?}

The idea that the knowledge-forming process of a truth commission should be transparent and inclusive for a non-expert public points to the same advantages of lay judges in the Assize court, namely the importance of a good reception by society and the inclusion of different views (not only expert views). These seem to be the advantages that truth commissions are looking for as well. If we compare them with the lay judges of the Assize court, can it be argued that they, too, are peers?

In contrast to the members of a jury, the commissioners of a truth commission are not randomly selected peers. They are specifically selected. That they cannot be random peers becomes clear when comparing the tasks of the jury of the Assize court with those of the members of a truth commission. In the Assize court, the jurors do not have to do any research. Their main task is to take the available information and the arguments presented into account when they decide on the guilt and the punishment of the accused. The tasks of the commissioners of a truth commission are more extensive and complex. For example, the primary objective of the Chilean National Truth and Reconciliation Commission was 'to clarify the truth about the serious human rights violations that occurred between 11 September 1973 and 11 March 1990' (Supreme Decree 355 Chile, 1990). Furthermore, the truth commission was instructed to formulate recommendations for reparations and prevention. In the mandate of the Chilean Rettig Commission, two concrete functions were formulated. The first was 'to establish a complete overview of the grave violations, their antecedents and their circumstances'; the second 'to gather information that will contribute to identify the victims and information about their fate and whereabouts' (Supreme Decree 355 Chile, 1990). The responsibility of the truth commissions includes tasks such as doing research, taking testimony from witnesses, analysing data, reporting to the public and composing a complete report on the topic. The commissioners ideally possess certain characteristics and capabilities relevant for these tasks, including research skills, experience working with victims and perpetrators, or the effective communication of complex, often highly moralized, issues to the public.

The commissioners of truth commissions, therefore, are not experts like the members of the expert commission, nor peer-laypeople like the members of 
the Jury of the Belgian Assize court. It can be argued that they occupy a place somewhere in between these two extremes. In the next section, I will examine what else is distinctive about them.

\section{WHO ARE THE COMMISSIONERS OF A TRUTH COMMISSION?}

\section{Comparison of Membership ${ }^{14}$}

A comparative analysis of the commissioners in the truth commissions of Argentina, Chile, El Salvador and South Africa leads to some interesting observations about their backgrounds and profiles. There are some remarkable similarities. As discussed above, the commissioners are not subject matter experts with regards to the conflict, but they clearly possess other kinds of expertise and characteristics. First of all, many commissioners have worked in academia. This is especially true for the commissions of Argentina, Chile and El Salvador. In the CONADEP, the commissioners had academic backgrounds in fields such as physics, engineering, philosophy, cardiology and mathematics. Many Chilean commissioners had an academic background, too, although they were mostly specialists in law, and one of the three members of the Salvadoran commission was also a law professor. Second, the commissions included many people who were active in human rights defence. Some, such as lawyers, did so professionally. For example, Ricardo Colombres was a defence attorney for political prisoners and relatives of disappeared persons in Argentina. Other members were human rights activists, members of human rights organizations or had taken a personal (and often public) stance against human rights abuses. Third, many members have a legal background: at least one in each of the four truth commissions. In Chile seven out of eight commissioners have a law degree. This commission had a clear legal focus. Although this major legal focus is remarkable, it was not one of the explicit criteria formulated in the supreme decree (Supreme Decree 355). In comparison, in the CONADEP the legal focus seems to be less important: the commission only contained one lawyer. Fourth, the commissions often contained members who could be expected to have the ability to explain complicated issues in a way understandable to a broad public, such as journalists, authors and politicians. Fifth, except for the commission of El Salvador, all the commissions contained either victims or people who could be seen as representatives of the victims. Several Chilean members had lived abroad in exile and several members of the South African commission had themselves been victims of human rights violations. The above-mentioned Ricardo Colombres is an example in the Argentinian case. Sixth, it would be true to say that all the commissioners had a good reputation and a degree of prestige. The legal decree which founded 
the Chilean commission is explicit that commissioners should be people with nationally recognized prestige. The CONADEP's report described the members of the commission in a similar way, as people who enjoy national and international prestige (CONADEP, 1984: chap 4.I). This explains why the commission contained, for instance, a famous author, the former rector of the University of Buenos Aires and a well-known cardiologist. In South Africa, the selection procedures of the commissioners had been a participative and democratic process that assured the prestige of the commissioners. The first phase of the procedure consisted in public nominations, which resulted in a list of well-known and respected people. Seventh, another apparently recurring characteristic of commissioners is ethical attitude and moral authority. Note that moral authority is not the same as good reputation and prestige. The latter refers to being well-known and respected, whereas moral authority is focused on the ability to take morally supported decisions or actions. People can have a good reputation or prestige for other reasons, for example because they are a good cardiologist. The condition of moral authority or a highly ethical attitude was clearly formulated in the Chilean decree. Although disputable, inviting people with a religious background (Argentina and South Africa) or judges (South Africa, El Salvador) can be interpreted in this way as well.

\section{General Profile of the Commissioners}

The comparison above suggests that the commissioners have some interesting characteristics in common. Based on this comparison, I formulate here a general profile of the commissioners based on the analysed cases. This general profile helps us understand the selection of the members and refers to the notions of objectivity and representation discussed above. The profile can be described by highlighting three tendencies that are independent of the commissioner's actual knowledge.

First of all, the high status of the commissioners forms part of their profile. Certain recurring characteristics, such as prestige, good reputation and moral authority, are all related to the importance of high status. The fact that the status of members is important can be related to Jasanoff's British model, where people of the elite are chosen to form part of the commission. Their presence contributes to a claim of objectivity. They can be said to present a view from everywhere. Their status has a positive influence on the authoritative character and overall acceptance of the knowledge they produce.

Second, another important characteristic which forms part of the profile is that the commissioners possess the intellectual (research) capacities necessary to perform various complex tasks, such as taking testimony from witnesses, analysing data, reporting to other commissioners and to the public, conducting an investigation, fact checking and composing a complete report. This can be 
expected from academics, lawyers and people who have previously worked in human rights defence.

Third, the concept of representation plays an important role. However, representation here has a broad meaning. The fifth characteristic discussed in the section above requires that victims or representatives of the victims form part of the commission. We can speak here of direct representation. Direct representation, in the way that I use it here, means that people represent the group of which they form part or that they represent others whom they are entitled to represent because of a direct and personal relationship with this person or group of people. As well as victims, other groups, such as political parties or religious communities, can also be represented in a direct way in the commission. Some commissions pursue representivity on this direct level, in the sense of the German model of a view from everywhere discussed above. When this is the case, the final composition of the commission also tells us something about how policymakers understand the conflict and how they see the society. To illustrate: in the Chilean commission only the political affiliations and ideas of the commissioners were taken into account to establish representativeness. The Chilean dictatorship had also affected indigenous groups; however, they were not represented. The South African TRC represented different political affiliations, but also different apartheid race categories and different religious beliefs. This seems to have been a more complete and realistic image of South African society. Thus, when representativeness is pursued, the selection of commissioners represents the social and political view on society of those who select them. Consequently, the commission's research will be conducted and the report will be written within the framework set by those pre-selections.

I now argue that truth commissions also contain members who represent the relevant parties in an indirect way. Indirect representation, in the way used here, implies that the members of a commission represent individuals or groups of people of which they are not a member or which they do not personally know. Some commissioners have professions, backgrounds or characteristics that help them to represent the parties involved. For example, psychologists, those who have worked with victims or those with a general human rights background can be assumed to be qualified to communicate with and understand witnesses. Even when not personally involved, they are assumed to be good at understanding the parties involved and representing them in the commission. They can often, in fact, represent more than one party. Further, to be good representatives, the commissioners should also be able to explain complicated issues in a way that is understandable to a broad public. Members with a profession such as journalism or authors certainly contribute in this regard. Those who represent in indirect ways have the ability to conduct research in order to understand what happened. They collect documents and testimonies and transform the available information about the complex and 
violent past into a report that makes it accessible and understandable to a broad public. They represent the different groups, by listening to them, by telling their stories (often in an indirect way) in the public report and through the formulation of recommendations for reparations for those wronged.

Although the commissioners might have good intentions, representation is never a completely transparent process. In his article 'The Representative Claim' (2006), Michael Saward speaks about an aesthetic moment in representation: 'There is an indispensable aesthetic moment in political representation because the represented is never just given, unambiguous, transparent. A representative - or someone making a representative claim - has necessarily to be creative. He or she has to mould, shape, and in one sense create that which is to be represented' (Saward, 2006: 310). The idea of indirect representation expects the commissioners to have the necessary creativity and insight to define not only what groups they should represent but also to define which aspects of the groups should be represented. The commission gives the groups they represent a voice to speak. At the same time, however, the claim of representation of the commissioners can also have a silencing effect on the represented (ibid.: 304). The commissioner, as a representative of certain groups, might appropriate their voices.

Although the commissioners might strive to represent others in an objective way, they will always have their own ideas, opinions and values that, inevitably, play a role in their decisions. They cannot fulfil the tasks related to their function as commissioners in a completely objective way, in the sense of being value-free. ${ }^{15}$ That is why not only the profile of the commissioner but also the composition of the commission is very important. A truth commission with a balanced composition might thus compensate for the (mild) biases of its individual members.

\section{CONCLUSION}

This chapter started from the observation that the commissioners of truth commissions seem to have divergent backgrounds. The questions "Why are the commissioners selected?' and 'Do they all fit a common epistemic profile?' motivated the research presented in this chapter. The first part of the chapter argued that the differences in their compositions can be made intelligible by referring to different ideals of objectivity. The objectivity claims made by the selection of the commissioners help to establish the authority of the commission. As a consequence, they are important for the reception of their future results. The second part of the chapter uncovered what kind of representative role the commissioners ought to play. In comparison with the members of the expert commissions of the EC (subject matter experts) and the jurors of the Assize court (laypeople and peers), the commissioners of 
truth commissions have a different epistemic profile. First of all, they are not all subject matter experts. Some of them might have certain knowledge about the topic they investigate, but that is not the (only) reason why they form part of the commission. Others are clearly laypeople (non-experts). In the cases of El Salvador and South Africa, the non-expert character of the members even seems to be a deliberate choice. However, that does not mean that any layperson could have been included in the commission. The commissioners of truth commissions have complex tasks and responsibilities and they need to possess certain characteristics and capabilities relevant to these. A comparison of the professions and backgrounds of the commissioners of the cases made it possible to formulate a general epistemic profile consisting of three main characteristics: first, some of the commissioners are selected because of their authoritative status; second, the commissioners possess the necessary skills and capacities, such as research skills; and, third, the commissioners represent the involved parties, directly or indirectly. Direct representation means that the commissioners have a direct link with the person or group they represent. Indirect representation means that although the commissioners are not directly related to the parties involved, they possess specific characteristics that help to represent them.

The analysis in this chapter draws on data from the truth commissions of Argentina, El Salvador, South Africa and Chile. As a consequence, I cannot argue that my analysis can be applied to all previous or future truth commissions. Every transitional justice context is different. The selection of the commissioners has a great impact, not only on the report but also on the transitional context itself. There is not one right way to compose a commission and there are no strict guidelines to be followed, but concepts such as objectivity, authority, status and representation seem to have an important bearing, independent of the commissions' different political contexts. Answers to questions such as How can objectivity and authority be reached? Who has the right profile to form part of a commission and to represent the relevant groups? and Who are these relevant groups? will always depend on the context. This chapter has highlighted the importance of these concepts and ideas for policymakers, presenting them as some aspects policymakers should take into account alongside other relevant factors. Reflection on the concepts might ideally lead to more awareness about the different factors and values at play, to deliberate decisions and to more transparency towards the public.

Commissions are often presented as objective bodies, for example by their representative composition (German model) or by depicting a commission with a 'view from nowhere'. However, I have shown in this chapter that neither those who select the commissioners nor the commissioners themselves can do their work in a completely objective way, in the sense of being free from all personal ideas, opinions and values (i.e. value-free objectivity). 
Therefore, policymakers and commissioners should be aware of how their own backgrounds might influence the results of their work. Furthermore, the inability to reach value-free objectivity on the personal level can be compensated for on the intersubjective level: objectivity can be approximated when agreement is achieved after a discussion among different members of a truth commission with a well-considered composition. ${ }^{16}$

\section{ACKNOWLEDGEMENTS}

The author would like to thank Briony Jones, Ulrike Lühe, Maarten Van Dyck, Berber Bevernage and Erik Weber for their advice and comments on earlier drafts.

\section{NOTES}

1. Not only the selection of the commissioners is important, but the members of the investigation teams that support the work of the commission also have a crucial impact on the working of truth commissions and their results. My reasons for focusing on the commissioners, and not on the investigators, are threefold. First, besides their epistemic tasks, the commissioners of a truth commission have a clearly public role as well. This makes their profile more complex and impactful than that of the investigators. Second, the members of research teams are often selected by or in consultation with the commissioners (e.g. Argentina and Chile), so the selection of the latter influences the selection of the former. Third, generally, there is less information available about who the investigators are, and about how and why they were selected.

2. Chile has had three truth commissions in total. In this chapter I will only discuss the first commission created in 1990. In 2003, a second commission was established by President Ricardo Lagos: the National Commission for Political Imprisonment and Torture (Comisión Nacional sobre Prisión y Tortura or Valech I Commission), which was a commission with a different scope (Bacic and Stanley, 2005: 1). In 2010, a third commission - the Valech II Commission - was established in order to compile a complete list of the victims of the human rights violations that had been investigated by the first two commissions.

3. The Ad Hoc Commission in El Salvador was tasked to investigate human rights violations committed by all top military officers during the war (Doggett and Kircher, 2005: 11; O'Shaughnessy and Dodson, 1999: 103).

4. Two of the 17 members, Dr Ramashala and Advocate de Jager, would resign before the commission's report was handed over (Tutu, 1999: 68).

5. 'The view from nowhere' is an expression Jasanoff borrowed from the philosopher Thomas Nagel.

6. The commissioners compared sources and assigned different degrees of certainty to the final conclusions of the cases. They differentiated between: overwhelming evidence (highly convincing evidence that supports the conclusion), substantial evidence (solid evidence that supports the conclusion), and sufficient evidence (when there is more supporting evidence than contradicting evidence) (United Nations, 1993: 21-2). 
7. In this chapter, I give the example of the Belgian jury system, which is partially different from jury systems in other countries such as the US. An important difference is that in the US, juries are involved in procedures in a variety of courts while in the Belgian judicial system, the jury is only involved in cases brought before the Assize court (Hof van Assisen - Cour d'Assises). Belgian law distinguishes three kinds of offence: misdaden (offences punishable with more than five years of imprisonment), wanbedrijven (offences punishable with imprisonment between eight days and five years and/or a fine), and overtredingen (offences punishable with imprisonment between one and seven days and/or a fine). The Assize court is officially responsible for misdaden (Traest, 2001: 27-8, see www.belgium .be). Political offences and offences perpetrated by means of the press can also be brought before the Assize court (Traest, 2001: 27-8). However, not all qualifying crimes are actually brought before the Assize court. Many of them are 'correctionalized' so that the offence is artificially transformed to a less serious one that can be brought before the correctional court (correctionele rechtbank or tribunal correctionnel), which operates without a jury (Traest, 2001: 28).

8. People also can have other kinds of expertise. Some can be called experts based on their practical experience instead of their theoretical knowledge on a topic.

9. 'Expert Groups Explained', European Commission, accessed 31 March 2020 at http://ec.europa.eu/transparency/regexpert/index.cfm?do=faq.faq\&aide=2

10. Definition from the online version of the Oxford English Dictionary.

11. The candidates on this final list all comply with five criteria: (1) entry in the voters' register; (2) possession of civil and political rights; (3) literacy; (4) aged between 28 and 65; and (5) no conviction of more than four months' prison time or more than 60 hours of community service (Federale Overheidsdienst - Justitie, 2010: 6; Art. 213, Law of December 21, 2009). Some additional groups are excluded (see Art. 218, Law of December 21, 2009 for the list) and gender and education balances are taken into account.

12. Interestingly, they can also be seen as peers of the accused, although, the principle of the jury in the Assize court is never explicitly described as the right of the accused to be tried by peers but as the right of the public to participate in the administration of justice (Traest, 2001: 28).

13. The complete list of professions excluded from jury service can be found in Art. 218 of the Law of December 21, 2009.

14. The information on the backgrounds of the commissioners was collected from different sources; for Argentina: Bulygin and Stigol (2007), Cassini (2009), Crenzel (2012: 37-8), Inforegion (2009), Vanoli (2005); for Chile: Kritz (1995: 463); for El Salvador: Americas Watch (1993: 8-9, 12), Mexico agreement (1991) - UN and El Salvador (1991: 263-72); for South Africa: Tutu (1999: 65-7), Verdoolaege (2005: 17).

15. Objectivity can be pursued in different ways. In her paper, 'The Irreducible Complexity of Objectivity', the philosopher Heather Douglas discusses eight operationally accessible and distinct senses of objectivity; value-free objectivity is one of them (2004: 462-4).

16. This is what Heather Douglas calls 'intersubjective objectivity' (2004: 462-4). 


\section{BIBLIOGRAPHY}

Americas Watch (1993), 'El Salvador. Accountability and Human Rights: The Report of the United Nations Commission on the Truth for El Salvador', News from Americas Watch, V (7), 1-39.

Amnesty International (2007), Truth, Justice and Reparation. Establishing an Effective Truth Commission, London: Amnesty International.

Ashforth, A. (1990), 'Reckoning Schemes of Legitimation: On Commissions of Inquiry as Power/Knowledge Forms', Journal of Historical Sociology, 3 (1), 1-22.

Bacic, R. and E. Stanley (2005), 'Dealing with Torture in Chile. Achievements and Shortcoming of the "Valech Report", accessed 21 November 2016 at www .menschenrechte.org

Bakiner, O. (2016), Truth Commissions: Memory, Power, and Legitimacy, Philadelphia, PA: University of Pennsylvania Press.

Bell, C. (2009), "Transitional Justice, Interdisciplinarity and the State of the "Field" or "Non-Field", International Journal of Transitional Justice, 3 (1), 5-27.

Brahm, E. (2007), 'Uncovering the Truth: Examining Truth Commission Success and Impact', International Studies Perspectives, 8, 16-35.

Buergenthal, T. (1995), 'The United Nations Truth Commission for El Salvador', in N. Kritz (ed.), Transitional Justice: How Emerging Democracies Reckon with Former Regimes. Volume I, Washington, DC: Institute of Peace, pp. 292-325.

Bulygin, E. and N. Stigol (2007), 'En Memoria de Eduardo A. Rabossi', Análisis Filosófico, 27 (1), 91-4.

Cassini, A. (2009), 'Gregorio Klimovsky (1922-2009)', Revista Latinoamericana de Filosofia, 35 (2), 389-92.

CONADEP (1984), 'Nunca Más (Never Again)', accessed 10 October 2013 at http:// www.desaparecidos.org/nuncamas/web/english/library/nevagain/nevagain_001.html

Crenzel, E. (2012), Memory of the Argentina Disappearances: The Political History of Nunca Más, New York: Routledge.

Doggett, M. and I. Kircher (2005), 'Human Rights in Negotiating Peace Agreements: El Salvador.' Paper presented at 'The Role of Human Rights in Agreements', The International Council on Human Rights Policy, Belfast.

Douglas, H. (2004), 'The Irreducible Complexity of Objectivity', Synthese, 138 (3), 453-73.

Dovi, S. (2017), 'Political Representation', in E. N. Zalta (ed.), The Stanford Encyclopedia of Philosophy, accessed 8 August 2018 at plato.stanford.edu/archives/ win2017/entries/political-representation/

Duquenne, S. (2015), 'Discussie Over Het Belang Van de Jury Binnen België en Een Kritische Evaluatie van de Juryrechtspraak van Het Hof van Assisen'. Master thesis, Ghent University, Ghent.

EC (2016), Communication to the Commission - Framework for Commission Expert Groups: Horizontal Rules and Public Register (Nr. C(2016)3300 final), accessed 28 February 2019 at http://ec.europa.eu/transparency/regexpert/PDF/C_2016_3300_F1 COMMUNICATION_TO_COMMISSION_EN.pdf

EC (n.d.), Register of Commission Expert Groups and Other Similar Entities, accessed 28 February 2019 at http://ec.europa.eu/transparency/regexpert/index.cfm?do=faq .faq \&aide $=2$

Federale Overheidsdienst - Justitie (2010), Het Hof van Assisen (Brochure Nr. $\mathrm{D} / 2010 / 7951 / \mathrm{NL} / 832$ ). 
Freeman, M. (2006), Truth Commissions and Procedural Fairness, New York: Cambridge University Press.

Government of Argentina (1983), Presidential Decree 187 Argentina, Pub. L. No. 187, accessed 21 November 2016 at http://www.derechos.org/ddhh/arg/ley/conadep.txt

Government of Chile (1990), Supreme Decree 355 Chile, Pub. L. No. 355, accessed 30 June 2014 at http://www.derechoshumanos.net/paises/America/derechos-humanos -Chile/informes-comisiones/Creacion-Comision-Rettig.pdf

Government of South Africa (1995), Promotion of National Unity and Reconciliation Act South Africa, Pub. L. No. Act 35.

Hayner, P. B. (1994), 'Fifteen Truth Commissions: 1974 to 1994: A Comparative Study', Human Rights Quarterly, 16 (4), 597-655.

Hayner, P. B. (1996), 'Commissioning the Truth: Further Research Questions', Third World Quarterly, 17 (1), 19-29.

Hayner, P. B. (2011), Unspeakable Truths: Transitional Justice and the Challenge of Truth Commissions, London: Routledge.

Inforegion (2009), 'A 25 Años Del Informe de la Conadep', accessed 3 August 2016 at http://www.inforegion.com.ar/vernota.php?tipo $=\mathrm{N} \& \operatorname{dis}=1 \&$ sec $=4 \& \mathrm{idPub}=93518$ \&id $=190862$

Jasanoff, S. (2011), 'The Practices of Objectivity in Regulatory Science', in C. Camic, N. Gross and M. Lamont (eds), Social Knowledge in the Making, Chicago: University of Chicago Press, pp. 307-38.

Jowdy, G. (1997), 'Truth Commissions in El Salvador and Guatemala: A Proposal for Truth in Guatemala', Boston College Third World Law Journal, 17 (2), 285-330.

Kritz, N. (ed.) (1995), Transitional Justice: How Emerging Democracies Reckon with Former Regimes. Volume II, Washington, DC: Institute of Peace.

Law of December 21, 2009 Belgium, Pub. L. No. 2009090000 (Wet Tot Hervorming van het Hof van Assisen) (2009, 21 December) in Belgisch Staatsblad (2010).

Mouralis, G. (2013), 'The Invention of "Transitional Justice” in the 1990s', in L. Israël and G. Mouralis (eds), Dealing with Wars and Dictatorships: Legal Concepts and Categories in Action, The Hague: Asser Press/Springer, pp. 83-100.

Office of the United Nations High Commissioner for Human Rights (2006), Rule-of-Law Tools for Post-Conflict States. Truth Commissions, New York and Geneva: OHCHR.

O'Shaughnessy, L. N. and M. Dodson (1999), 'Political Bargaining and Democratic Transitions: A Comparison of Nicaragua and El Salvador', Journal of Latin American Studies, 31 (1), 99-127.

Oxford English Dictionary (n.d.), 'Peer', Oxford English Dictionary, accessed 7 February 2019 at www.oed.com

Saward, M. (2006), 'The Representative Claim', Contemporary Political Theory, 5, 297-318.

Shea, D. (2000), The South African Truth Commission - The Politics of Reconciliation, Washington, DC: United States Institute of Peace Press.

Teitel, R. (2003), 'Transitional Justice Genealogy', Harvard Human Rights Journal, 16, 69-94.

Traest, P. (2001), 'The Jury in Belgium', Revue Internationale de Droit Pénal, 1 (72), $27-50$.

Tutu, D. (1999), No Future Without Forgiveness, New York: Doubleday.

United Nations (1993), De la Locura a la Esperanza. La Guerra de 12 Años en El Salvador. Informe de la Comisión de la Verdad 1992-1993. San Salvador.

United Nations and El Salvador 1990-1995 (1991), 'Mexico Agreements', UN Doc. No. A/46/553-S/23130, United Nations Blue Books Series, vol. IV, New York: UN, 
Department of Public Information, accessed 9 January 2017 at http://www.usip.org/ publications/peace-agreements-el-salvador

Vanoli, A. (2005), 'Veinte Años Después: Acerca de la Conadep', Encrucijadas, 30 (Universidad de Buenos Aires).

Verdoolaege, A. (2005), 'Reconciliation. The South African Truth and Reconciliation Commission: Deconstruction of a Multilayered Archive'. PhD dissertation, Ghent University, Ghent.

Villa-Vicencio, C. and W. Verwoerd (2000), 'Constructing a Report Writing up the "Truth", in R. Rotberg and D. Thompson (eds), Truth v. Justice: The Morality of Truth Commissions, Princeton, NJ: Princeton University Press, pp. 279-94.

Vinjamuri, L. and J. Snyder (2004), 'Advocacy and Scholarship in the Study of International War Crime Tribunals and Transitional Justice', Annual Review of Political Science, 7 (1), 345-62. 